\title{
Endodontic Treatment of the Teeth with Different Root Canal Curvatures - Two Case Reports
}

\author{
Katarina Beljić-Ivanović, Nevenka Teodorović, Dejan Ostojić \\ Clinic for Restorative Dentistry and Endodontics, School of Dentistry, University of Belgrade, Belgrade, Serbia
}

\begin{abstract}
SUMMARY
Endodontic treatment of the teeth with severe root canal curvatures has become one of the greatest problems in clinical practice. Recently, new instruments and techniques have been introduced in the endodontic procedure. The aim of this study was, on the basis of clinical practice, to show the possibilities of the endodontic treatment in the teeth with severely curved root canals, after dependable decision about endodontic instruments and techniques. This article presents a complete endodontic procedure in two teeth with different curvature shape of the root canal in patients that were treated at the Department of Restorative Dentistry and Endodontics, School of Dentistry, Belgrade. Coronal to apical "crown down" technique was used for the root canal preparation with hand NiTi ProTaper instruments with progressive multicone design. The main reasons for choosing manual technique were complexity, shape of presented curvatures and better tactile sensation control of canal instruments in order to avoid possible mistakes and complications. Clinical X-rays of the teeth with permanent obturation clearly showed that extremes of the root canal morphology could be successfully solved by the right choice of all factors during endodontic procedure.
\end{abstract}

Keywords: root canal; shape of the canal curvature; endodontic preparation

\section{INTRODUCTION}

During endodontic treatment, there is a demand to follow a well defined phases. Approaching the endodontic space, identification of the canal entrances and negotiation the canals are some of them. The main canal should be prepared in the form of continual cone (elongated cone) in order to make a space for the copious and dynamic irrigation, to clean the root canal and finally to obturate the endodontic space.

There are many factors that have impact on the quality of the chemomechanical cleaning of the root canal system. Most of them are easily controlled by endodontist, but internal morphology of the canal system, which has direct impact on the success of the treatment, is completely out of practitioner's control. Every root canal has its own form, and knowing the curvature, shape and radius of the curve is essential for the decision of adequate preparation and obturation methods. Because of that, one should systematically learn of variability of the root canals from the literature [1], and in the practice should use all available recourses to register and define specific root canal shapes, which are not easily seen by radiography.

A good classification of the canal curve shapes is important for selecting the samples for research as well as for practice. Forms of the root canals could be classified as: I - straight, C - curvature in whole length, J - curvature in the apical part, and $\mathrm{S}$ - more than one curvature [2], or: primary, secondary and tertiary curvatures, where the primary are shapes $\mathrm{C} i \mathrm{~J}$, secondary is $\mathrm{S}$ and tertiary are double S [3]. During instrumentation of the curved canal, it is important to keep its original shape as well as the position and the diameter of the apical foramen. The most frequent mistakes and aberrations happen because of the pressure that instruments make on the matched walls of the curvature. That leads to: canal transportation, formation of the ledges, perforations, apical widening in lachrymal shape or "hourglass" [4]. Higher degree of curvature is leading to the higher risk of complications.

The aim of his study was, on the basis of clinical practice, to show the possibilities of the endodontic treatment in the teeth with severely curved root canals, and to suggest that dependable decision about endodontic instruments and techniques is the most important demand for the success of the endodontic therapy.

\section{CASE REPORT 1: SECOND LEFT MAXILLARY PREMOLAR}

A 42-year-old patient presented to the Clinic for Restorative Dentistry and Endodontics, School of Dentistry in Belgrade because of spontaneous, severe and flamed pain in the maxillary region on the left side. After taking history, clinical examination and performing diagnostic tests, the pulp inflammation was diagnosed. Endodontic treatment was proposed to the patient and after his consent, the treatment started. On the preoperative radiograph, double curvature of the root was noticed as well as very complicated anatomy of the root canal with S curvature and disappearance of the canal in the middle part of the root (Figure 1).

After giving anaesthesia, the rubber dam was placed. Firstly, wide access cavity was prepared and trepana- 
tion of the pulp chamber was done, then, entrances of the canals were located. During exploration of the canals using canal instruments type K-flex files No. 10 (Dentsply/ Maillefer, Switzerland), it was found that the canal was splitting in the middle part on two branches, which were joined together in the apical part of the canal. Preparation of the root canal up to the place of branching the canal

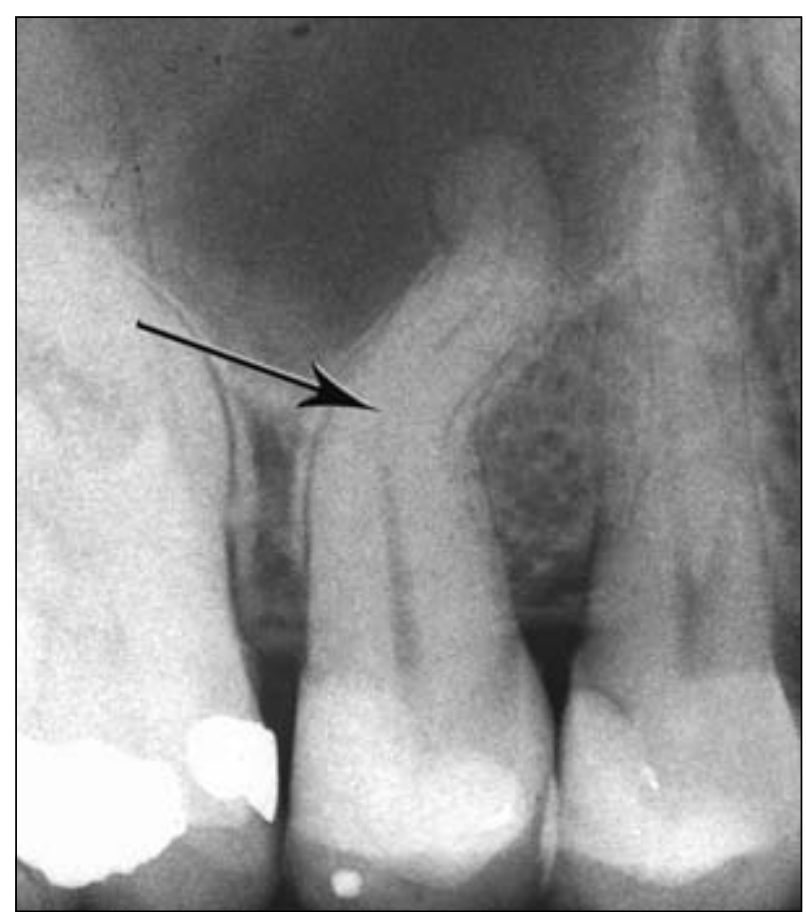

Figure 1. X-ray of the second maxillary bicuspid with canal separation at the mid-root level (arrow) and S-shaped curvature

Slika 1. Radiogram drugog levog maksilarnog premolara s razdvojenim kanalima u srednjem delu korena (strelica) i krivinom S oblika

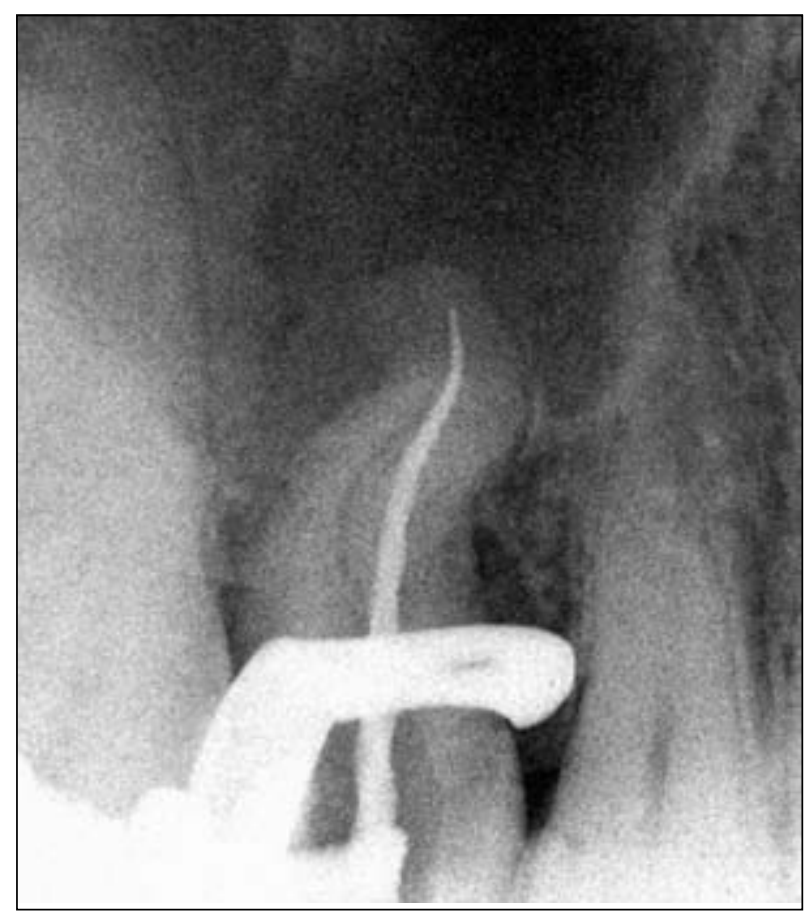

Figure 2. Working length $X$-ray of the palatal root canal with ProTaper S2 hand instrument and rubberdam with clamp in place

Slika 2. Odontometrijski radiogram palatalnog kanala sa ProTaper S2 ručnim instrumentom i postavljenim koferdamom sa klamericom was done using manual NiTi instruments with progressive cone ProTaper (Dentsply/Maillefer, Switzerland) and Crown- down technique with copious irrigation of $1 \% \mathrm{NaOCl}$ and lubrication (Canal+, Septodont, France). Sequences of the preparation were: S1 with diameter of $0.17 \mathrm{~mm}$ on the tip and cone growth from $2 \%$ to $11 \%$, S2 with diameter of $0.20 \mathrm{~mm}$ on the tip and cone growth from

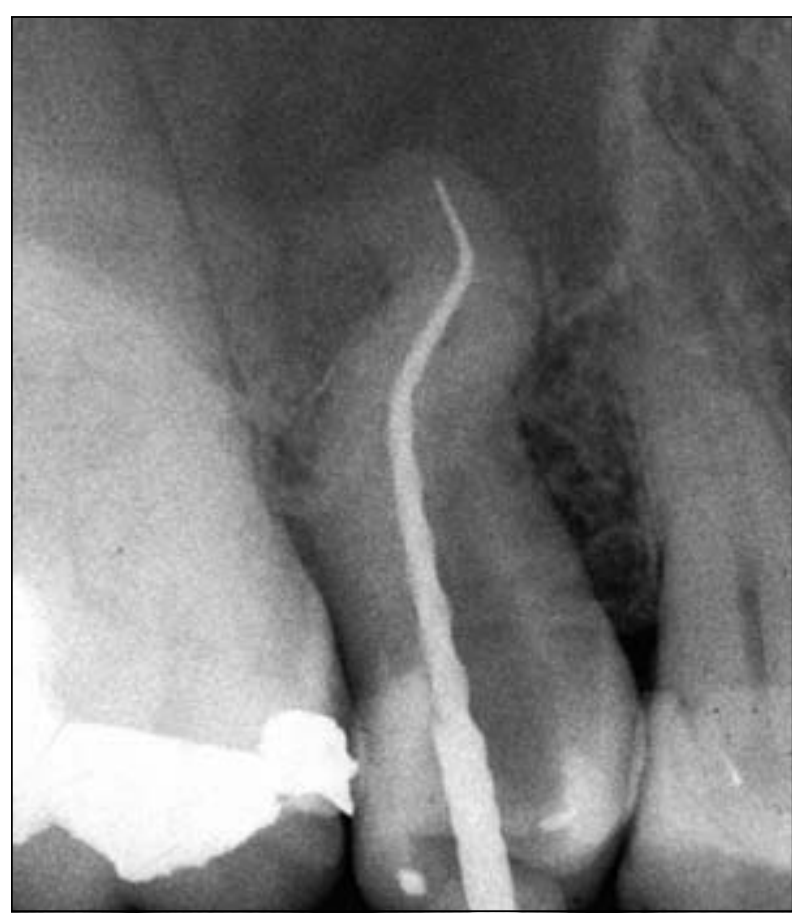

Figure 3. Working length $X$-ray of the buccal root canal with ProTaper S2 hand instrument with no rubber dam and clamp on tooth

Slika 3. Odontometrijski radiogram bukalnog kanala sa ProTaper S2 ručnim instrumentom bez koferdama i klamerice na zubu

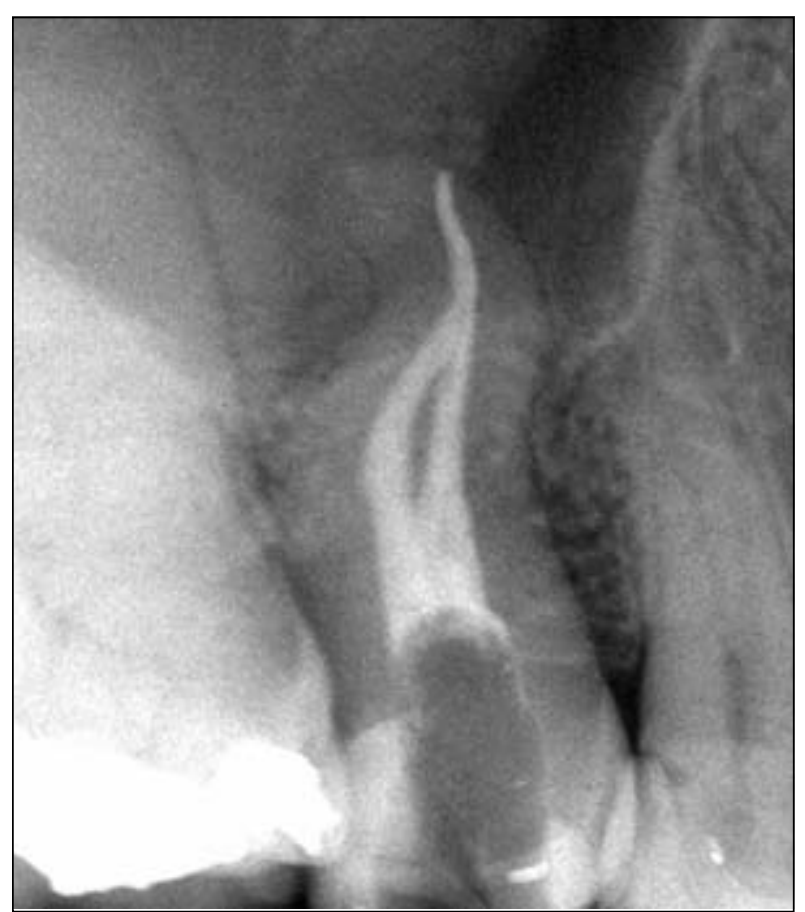

Figure 4. X-ray of the tooth with filled root canals Slika 4. Radiogram zuba s opturiranim kanalima 
$4 \%$ to $11.5 \%$ and $\mathrm{Sx}$ with diameter of $0.19 \mathrm{~mm}$ on the tip and cone growth from $3.5 \%$ to $20 \%$. After finishing the coronal and middle part of the root canal, the working length was determined using apex locator Apex NRG XFR (NRG Medic, Israel) in combination with radiography. Analysing the radiographs, it was obvious that because of radio opacity of the clamp, some important details about root canal morphology could not be seen (Figure 2). For that reason, it was removed while taking next radiographies (Figure 3). The apical third was prepared according to the sequences for working with hand ProTaper instruments from S1, to S2 and F1 $(0.20 \mathrm{~mm}$, cone at the tip of $7 \%)$ and finally $\mathrm{F} 2$ instrument with apical cone of $8 \%$ and diameter of $0.25 \mathrm{~mm}$.

Irrigation was managed following the endodontic protocol: $1 \%$ of $\mathrm{NaOCl}, 10 \%$ of citric acid and the last irrigant $0.5 \%$ of $\mathrm{NaOCl}$. Paper points in the diameter of the last canal instrument were used for drying the canal. Top Seal paste (Dentsply/Maillefer, Switzerland) was placed in the canal using hand F1 instrument. Main gutta-percha point had cone 06 and its apical diameter was the same as diameter of the last canal instrument. Accessory guttapercha points were placed in the technique of cold lateral compaction (Figure 4).

\section{CASE REPORT 2:}

\section{SECOND LEFT MANDIBULARY MOLAR}

A 49-year-old patient presented to the Clinic for Prosthetic Dentistry, School of Dentistry in Belgrade because of prosthetic therapy. The complex therapy also included endodontic treatment of the teeth. After taking history and clinical examination, endodontic therapy of the second left mandibular molar was firstly proposed due to necrosis of the pulp. After detailed explanations, the patient accepted the therapy. Ortopnatomography (OPT) did not show

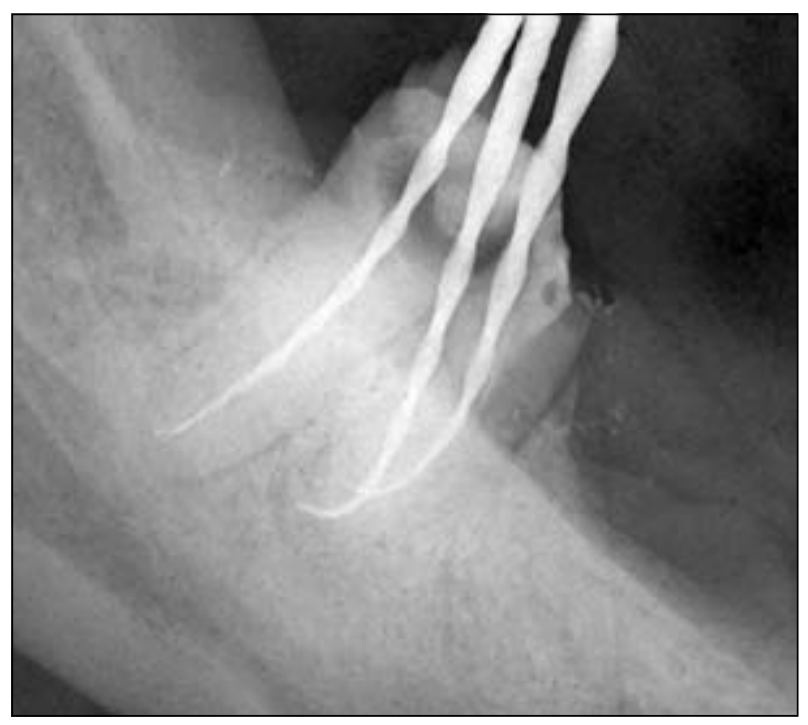

Figure 5. Working length $X$-ray of mandibular left second molar with hand ProTaper $\mathbf{2}$ instruments in all three root canals. Mesial canals have I curvature shape

Slika 5. Odontometrijski radiogram drugog levog mandibularnog molara sa ručnim ProTaper S2 instrumentima u sva tri kanala. Mezijalni kanali s krivinom u obliku slova J.

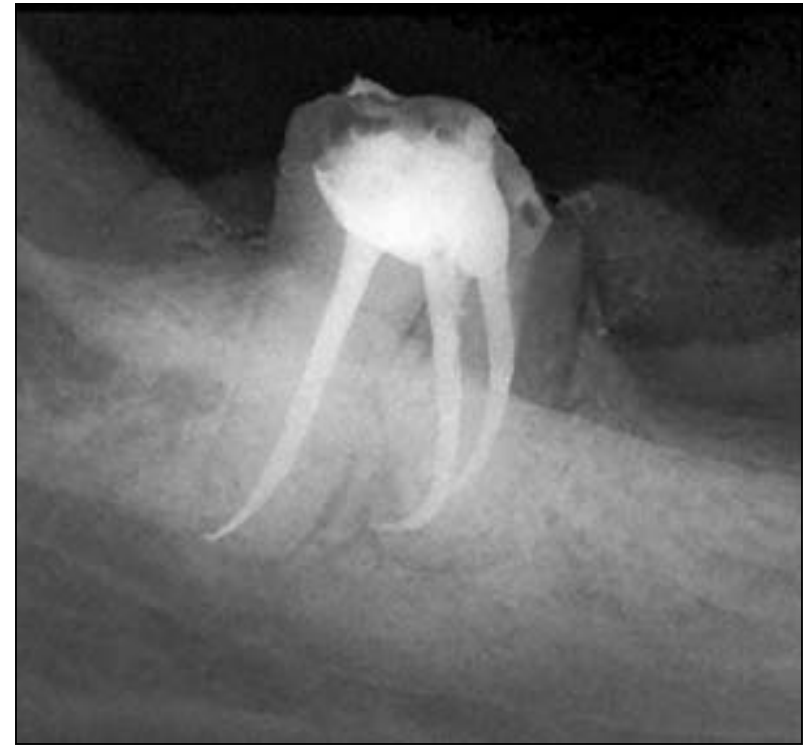

Figure 6. X-ray of the tooth with filled root canals Slika 6. Radiogram konačno opturiranih kanala

significant curvature of the root canals. After pulp trepanation and preparation of the root canal openings during initial exploration of the root canal using K-flex files No. 08 and 10 , severe curvature in the apical part of the mesial root canals, which left curved tips of the files, was noticed. Using ProTaper instruments and Crown down technique, the coronal and middle part of the three canals were prepared synergistically with copious irrigation with $1 \%$ of $\mathrm{NaOCl}$, lubrication with Canal+ and recapitulation to the apex. Using apex locator and K-flex files No. 15, the working length was determined. The apical third was prepared using ProTaper NiTi instruments S1 and S2, because of extremely curved mesial canals. In this phase of preparation, radiography with S2 instruments in all three canals was done in order to make canal morphology more clear and visible (Figure 5). Mesial canals were prepared to F1 and distal to F2 ProTaper instruments. The canals were irrigated, dried and obturated using Top Seal paste and gutta-percha points. In the distal canal, paste was placed using lentulo-spiral while in mesial, the paste was placed with manual technique previously described. After placing the main gutta-percha point, the accessory gutta-percha points were added with lateral compaction technique up to total obturation of all three canals (Figure 6).

\section{DISCUSSION}

Cases with different and extreme shapes of the root canals shown in this study were endodontically treated using corono-apical Crown-down technique due to its numerous benefits proved in clinical practice $[5,6,7]$. The advantage of this technique is primarily widening and shaping the coronal parts of the root canals with greater cone $(4 \%$, $6 \%, 8 \%)$ than standardized (2\%), which makes approach to the curved, narrowed or difficult for preparation parts of the root canals easier and straight. Beside, Crown-down technique allows removing the great amount of the debris from the canals, preparing the container for the irrigationg 
solutions. Also it reduces contact between canal instrument with canal walls and possibility to transport the debris in the apical periodontium, facilitates control and keeping the working length as well as preparation of the apical part of the root canal.

To explore the canal, steel instruments were used because of their limited elasticity when deforming in the curved canal, they can show intensity, shape and direction of the canal curve, which is not always easily obtained from radiography.

The use of NiTi instruments with progressive growth of the cone like ProTaper, facilitated the preparation in all sequences of the Crown down technique along the canal. Manual technique using balanced forces instead of rotary enabled dependable and easier preparation of extremely curved canals $[5,8]$.

Compressive technique of cold gutta-percha lateral compaction provided satisfied results in three dimensional obturation of the root canal system.

High quality endodontic treatment and obturation of the root canal system prevent or stop the infection of the vital periodontal tissue, which is responsible for reparatory processes.

\section{CONCLUSION}

During endodontic treatment of severely curved root canals with J and $\mathrm{S}$ curve using Crown down technique and NiTi hand instruments with greater cone, neither mistake nor deviation from the original shape of the root canal happened. A good choice of endodontic instruments and an adequate technique of preparation, along with precision and capability of the endodontist are the key factors for successful endodontic treatment even in very complex root canal systems.

\section{REFERENCES}

1. Sonntag D, Stachniss-Carp S, Stachniss C, Stachniss V. Determination of root canal curvatures before and after canal preparation (part II): A method based on numeric calculus. Aust Endod J. 2006; 32:16-25.

2. Dobo-Nagy C, Szabo J. A mathematically based classification of root canal curvatures on natural human teeth. J Endodont. 1995; 21:557-60.

3. Kartal N, Cimilli H. The degrees and configurations of mesial canal curvatures of mandibular first molars. J Endodont. 1997; 23:358-62.

4. Schafer E, Diez C, Hoppe W, Tepel J. Roentgenographic investigation of frequency and degree of canal curvatures in human permanent teeth. J Endodont. 2002; 28:211-6.

5. Cohen S, Burns RC. Pathways of the Pulp. St Louis: Mosby Inc; 2002.

6. Bergenholtz G, Horsted-Bindslev P, Reit C. Textbook of Endodontology. Oxford, UK: Blackwell Munksgaard; 2003.

7. Paque F, Musch U, Hulsmann M. Comparison of root canal preparation using RaCe and ProTaper rotary NiTi instruments. Int Endod J. 2005; 38:8-16.

8. Bergmans L, Van Cleynenbreugel J, Beullens $M$, Wevers $M$, Van Meerbeek B, Lambrechts P. Progressive versus constant tapered shaft design using NiTi rotary instruments. Int Endod J. 2003; 36:288-95.

\author{
Address for correspondence \\ Katarina Beljić-Ivanović \\ Clinic for Restorative Dentistry and Endodontics \\ Rankeova 4, 11000 Belgrade \\ Serbia \\ Phone: +381 (0)638836 760 \\ Email: vladaivanovic@hotmail.com
}




\title{
Endodontsko lečenje zuba s različitim oblicima krivina korenskih kanala - dva prikaza iz prakse
}

\author{
Katarina Beljić-Ivanović, Nevenka Teodorović, Dejan Ostojić \\ Klinika za bolesti zuba, Stomatološki fakultet, Univerzitet u Beogradu, Beograd, Srbija
}

\begin{abstract}
KRATAK SADRŽAJ
Endodontsko lečenje zuba s jako zakrivljenim korenovima je značajan problem u praksi. Primena novih instrumenata i tehnika u lečenju ovakvih zuba poslednjih godina je postala sve izvesnija. Cilj ovog rada je bio da se na primerima iz kliničke prakse ukaže na mogućnost endodontskog lečenja zuba s veoma izraženim krivinama kanala korena nakon pravilnog izbora endodontskih instrumenata, odnosno tehnike instrumentacije. $U$ ovom radu je prikazan celokupni endodontski postupak lečenja dva zuba pacijenata Klinike za bolesti zuba Stomatološkog fakulteta u Beogradu sa različitim oblicima krivine centralnog korenskog kanala. Primenjena je krunično-apeksna "crown-down" tehnika preparacije uz korišćenje ručnih nikl-titanijumskih instrumenata tipa ProTaper s progresivnom multikoničnošću. Osnovni razlozi za odabir ručne tehnike preparacije bili su složenost morfologije, oblik prikazanih krivina i bolja taktilno-senzorna kontrola kanalnih instrumenata; cilj je bio da se izbegnu moguće greške i komplikacije. Prikazani radiografski snimci zuba sa jasno opturiranim kanalnim sistemom pokazuju da su i ekstremi morfološkog izgleda kanala rešivi pravilnim odabirom svih činilaca endodontske procedure.
\end{abstract}

Ključne reči: korenski kanal; oblik krivine kanala; endodontska preparacija

\section{UVOD}

Tokom endodontskog lečenja svakog kanalnog sistema zuba neophodno je poštovati definisane faze. Endodontskom prostoru se mora pravilno pristupiti, moraju se prepoznati svi ulazi u kanale i obezbediti njihova prohodnost čitavom dužinom. Instrumentacijom treba oblikovati prostor centralnog kanala u obliku kontinuiranog konusa (izdužene kupe) i na taj način stvoriti prostor za obilnu i dinamičnu irigaciju i čišćenje čitavog kanalnog sistema, odnosno za trodimenzionalno hermetičko zaptivanje.

Na kvalitet hemomehaničke obrade kanala korena utiču mnogi faktori. Najveći broj ovih faktora je pod kontrolom terapeuta, ali je unutrašnji izgled kanalnog sistema, koji direktno uslovljava tok i ishod lečenja, van uticaja endodontiste. Svaki korenski kanal ima svoj poseban oblik, a poznavanje povijenosti, oblika i prečnika krivine je ključno u odabiru adekvatne metode preparacije i opturacije. Zbog toga se moraju detaljno proučiti svi mogući varijeteti iz prikaza u literaturi [1], a u kliničkom radu svim dostupnim sredstvima što potpunije zabeležiti i definisati specifičnosti korenskih kanala, koje uglavnom nisu vidljive na kliničkom radiogramu.

Pouzdana klasifikacija oblika krivine je važna kako za odabir uzoraka u različitim istraživanjima, tako i za klinički rad. Oblici korenskog kanala se mogu klasifikovati kao: I - prav, C - krivina duž celog kanala, J - apeksna krivina i S - multipla krivina [2], ili na: primarne, sekundarne i tercijarne, gde primarnim pripadaju oblici C i J, sekundarnim S, a tercijarnim oblici dvostrukog slova S [3]. Tokom instrumentacije povijenog kanala mora se voditi računa o očuvanju njegovog originalnog oblika, kao i pozicije i prečnika apeksnog foramena. Najčešće greške i aberacije javljaju se zbog pritiska koji instrument vrši na naspramne zidove krivine, što dovodi do transportacije kanala, stvaranja "stepenika", perforacije, apeksnog proširenja u obliku suze ili peščanog sata [4]. S povećanjem stepena povijenosti povećava se i rizik od nastanka navedenih komplikacija.

Cilj ovog rada je bio da se na primerima iz kliničke prakse ukaže na mogućnost endodontskog lečenja zuba s veoma izraženim krivinama kanala korena, odnosno da ukaže da pravilan izbor endodontskih instrumenata i tehnike instrumentacije, koje su najvažniji uslov za uspeh endodontskog lečenja.

\section{PRIKAZ PRVOG SLUČAJA: DRUGI LEVI MAKSILARNI PREMOLAR}

Pacijent star 42 godine javio se na Kliniku za bolesti zuba Stomatološkog fakulteta u Beogradu zbog jakih, spontanih sevajućih bolova u predelu gornje vilice s leve strane. Na osnovu anamneze, kliničkog pregleda i svih dijagnostičkih testova postavljena je dijagnoza akutnog zapaljenja pulpe. Pacijentu je predloženo endodontsko lešenje, što je posle njegove saglasnosti i urađeno. Na radiogramu pre operacije primećeni su dvostruka povijenost celog korena, izuzetna komplikovanost kanalnog sistema s krivinom u obliku slova S i prekidi kontinuiteta kanala oko sredine korena (Slika 1).

Nakon primene anestetičkog rastvora postavljen je koferdam. Prepariran je prostran pristupni kavitet, urađena trepanacija i pronađen ulaz u kanal. Eksploracijom kanalnim instrumentima tipa K-flex turpije broj 10 (Dentsply/Maillefer, Switzerland) ustanovljeno je račvanje u srednjoj trećini na dva odvojena kanala, koji su se u apeksnoj trećini ponovo spojili u jedan. Preparacija je urađena tzv. crown-down tehnikom nikl-titanijumskim (NiTi) ručnim ProTaper instrumentima (Dentsply/Maillefer, Switzerland) progresivne multikoničnosti do mesta spajanja dva kanala u jedan, uz obilnu irigaciju jednoprocentnim rastvorom natrijum-hipohlorita i lubrikaciju (Canal Plus, Septodont, France). Sekvence preparacije su bile sledeće: S1 kalibra $0,17 \mathrm{~mm}$ na vrhu i priraštaja koničnosti od $2 \%$ do $11 \%$, S2 kalibra $0,20 \mathrm{~mm}$ i porasta koničnosti od $4 \%$ do $11,5 \%$ i Sx sa promerom $0,19 \mathrm{~mm}$ i priraštajem koničnosti od 3,5\% do $20 \%$. Posle obrađene krunične i srednje trećine kanala određena je radna dužina kombinacijom elektronskog apeksnog lokatora Apex NRG XFR (NRG Medic, Israel) i rendgenografije. Posmatranjem i analizom odontometrijskog radiograma zaključeno je da kvačica koferdama maskira važne informacije o kanalnom sistemu zuba (Slika 2) i zbog toga je uklanjana pri 
svakom sledećem snimanju (Slika 3). Apeksna trećina je preparirana prema utvrđenim sekvencama za rad ručnim ProTaper instrumentima od S1, preko S2 i F1 (0,20 mm, koničnost na vrhu 7\%), do F2 finirajućeg instrumenta apeksne koničnosti od $8 \%$ i promera od $0,25 \mathrm{~mm}$.

Konačna irigacija je urađena po utvrđenom endodontskom protokolu: $1 \%$ rastvora natrijum-hipohlorita, $10 \%$ rastvora limunske kiseline i, kao poslednji irigans, $0,5 \%$ rastvora natrijum-hipohlorita. Sušenje kanala pre opturacije je obavljeno papirnim poenima promera koji je odgovarao kalibru poslednjeg kanalnog instrumenta. Pasta Top Seal (Dentsply/Maillefer, Switzerland) je nanesena ručnim F1 instrumentom, a centralni gutaperka-poen bio je koniciteta $06 \mathrm{i}$ apeksnog promera poslednjeg kanalnog instrumenta. Kanali su dopunjeni akcesornim gutaperka-poenima primenom hladne lateralne kompakcije (Slika 4).

\section{PRIKAZ DRUGOG SLUČAJA: DRUGI LEVI MANDIBULARNI MOLAR}

Pacijentkinja stara 49 godina se javila na Kliniku za stomatološku protetiku Stomatološkog fakulteta u Beogradu radi zbrinjavanja fiksnim metalokeramičkim nadoknadama, koje su zahtevale endodontsku pripremu zuba. Posle anamneze i kliničkog nalaza svih zuba odlučeno je da se, zbog multiplog kanalnog sistema i dijagnostikovane nekroze pulpe, prvo endodontski leči drugi donji molar s leve strane vilice. Pacijentkinja se saglasila sa detaljno obrazloženim planom lečenja. Na ortopantomografskom snimku nije uočena značajnija povijenost korenskih kanala. Posle urađene trepanacije i obrade ulaza u kanale inicijalnom eksploracijom turpijama K-flex kalibra 08 i 10 ustanovljena je velika apeksna povijenost mezijalnih kanala, koja je ostavila značajnu deformaciju vrhova ovih instrumenata. Tehnikom crown-down i ProTaper instrumentima preparirana je krunična i srednja trećina sva tri kanala uz obilnu irigaciju jednoprocentnim rastvorom natrijum-hipohlorita, lubrikaciju sa Canal Plus i stalnu rekapitulaciju do apeksne trećine. Elektronskim apeksnim lokatorom i primenom turpije K-flex broj 15 određena je radna dužina. Apeksna trećina je veoma pažljivo obrađivana ručnim NiTi instrumentima ProTaper S1 i S2, s obzirom na ogromnu povijenost mezijalnih kanala. $\mathrm{U}$ ovoj fazi preparacije urađena je radiografija sa S2 ProTaper u sva tri kanala radi jasnijeg i vidljivijeg uočavanja oblika krivine (Slika 5). Mezijalni kanali su završno preparirani do F1, a distalni do F2 ProTaper instrumenta. Kanali su isprani, osušeni i opturirani pastom TopSeal i gutaperka-poenom. U distalni kanal pasta je nanesena mašinski lentulospiralom, a u mezijalne opisanom ručnom tehnikom i postavljanjem centralnog gutaperka-konusa.
Lateralnom kompakcijom su dodavani akcesorni poeni do potpune opturacije sva tri kanala (Slika 6).

\section{DISKUSIJA}

Prikazani slučajevi različitih i ekstremnih oblika povijenosti korenskih kanala su endodontski lečeni primenom kruničnoapeksne, tzv. crown-down tehnike zbog svojih višestrukih prednosti dokazanih u praksi $[5,6,7]$. Osnovna prednost ove tehnike je primarno širenje i oblikovanje početnih delova korenskog kanala instrumentima veće koničnosti $(4 \%, 6 \%, 8 \%)$ od standardnih (2\%), što omogućava olakšan i pravolinijski pristup zakrivljenim, suženim ili teže obradivim delovima centralnog korenskog kanala. Pored toga, ovom tehnikom se otklanja najveći deo tkivnog detritusa, obezbeđuje prostran rezervoar za obilnu i efikasnu irigaciju, smanjuje dodirna površina kanalnog instrumenta sa zidovima kanala i mogućnost prebacivanja debrija u periodontalno tkivo, obezbeđuje bolja kontrola i očuvanje radne dužine, odnosno preparacija apeksnog dela kanala.

Za eksploraciju kanala korišćeni su čelični instrumenti jer se, zbog svoje ograničene elastičnosti, deformišu u povijenom kanalu i na taj način odslikavaju intenzitet, oblik i smer krivine, koji nije uvek moguće otkriti na kliničkoj radiografskom snimku.

Primena NiTi instrumenata s progresivnim povećanjem koničnosti tipa ProTaper omogućavao je uspešnu preparaciju u svim sekvencama crown-down tehnike duž čitavog korenskog kanala. Odabir ručne tehnike primenom pokreta "balansirane sile" umesto mašinske, s punom rotacijom, omogućio je sigurniju i predvidljivu preparaciju veoma zakrivljenih kanala $[8,5]$.

Kompresivna tehnika lateralne kondenzacije hladne gutaperke je potpuno ispunila zahteve za trodimenzionalnim zatvaranjem preparisanog kanalnog sistema.

Pravilno izvedena endodontska terapija i konačna opturacija kanalnog prostora sprečava ili zaustavlja infekciju vitalnog periodontalnog tkiva, koje je odgovorno za reparacijske procese.

\section{ZAKLJUČAK}

Tokom endodontske preparacije veoma povijenih korenskih kanala s krivinama u obliku slova J i S crown-down tehnikom i NiTi ručnim instrumentima veće koničnosti nije došlo do pojave grešaka, niti odstupanja od originalnog oblika kanala. Pravilan izbor endodontskih instrumenata i odgovarajuće tehnike preparacije kanala, kao i preciznost i veština terapeuta omogućavaju uspeh endodontskog lečenja i kod vrlo komplikovanih kanalnih sistema. 